\title{
Evaluation of cardiovascular autonomic function in diabetics and normal individual by using standard autonomic function tests and heart rate variability
}

\author{
Prakash SB ${ }^{1}$, Md. Eajaz Ahmed Shariff,"* \\ ${ }^{\mathbf{1}}$ Assistant Professor, ${ }^{\mathbf{2}}$ Associate Professor, Dept. of Physiology, ${ }^{\mathbf{1}}$ Koppal Institute of Medical Sciences, Koppal, Karnataka, ${ }^{\mathbf{2}} \mathrm{Al}-\mathrm{Azhar}$ \\ Medical College, Ezhalloor, Thodupuzha, Kerala, India \\ *Corresponding Author: Md. Eajaz Ahmed Shariff \\ Email:dreajaz@gmail.com
}

Received: $18^{\text {th }}$ August, 2018

Accepted: $28^{\text {th }}$ October, 2018

\begin{abstract}
In diabetic patients cardiac autonomic neuropathy is a serious and common complication. Unrecognized cardiac autonomic neuropathy can prove fatal in them.

Objective: The present study was done for evaluation of standard cardiovascular reflex tests, heart rate variability and QTc interval as a tool in diagnosis of CAN in diabetic patients.

Materials and Methods: Randomly newly detected type 2 diabetic hundreds patients attending the Out Patient Department attached to J.J.M. Medical College were selected for the study. The results were compared with 50 controls. Niviqure software was used to analyse HRV in terms of Low Frequency, High Frequency the ratio and QTc interval.

Results: Our study has shown that the values of different tests were within normal limits but, the values were slightly altered in diabetic patients with CAN score > 0 . (p < 0.01). Out of 100 diabetic patients 41 individuals had borderline CAN and 25 patients had QTc values > 440. There was no significant decrease in LF, HF and LF/HF ratio. Among cardiovascular tests, hand grip test and QTc interval showed significant changes.

Conclusion: In this study blood pressure response to hand grip test and QTC interval measurement have shown some promise as useful test for screening diabetics patients for CAN.
\end{abstract}

Keywords: Cardiac autonomic neuropathy, Diabetes mellitus, Heart rate variability, Hand grip test, Valsalva ratio.

\section{Introduction}

Long term complications of diabetes includes neuropathies which affect upto $50 \%$ of patients. ${ }^{1-2}$ Most common neuropathies are chronic sensorimotor distal symmetric polyneuropathy and autonomic neuropathy. Diabetic autonomic neuropathy (DAN) can involve entire autonomic nervous system. It is manifested by involvement of one or more body organ systems..$^{3-4}$

Despite its significant negative impact on survival and quality of life in people with diabetes, DAN is among the least recognized and understood complications of diabetes. ${ }^{5}$ DAN that accompany diabetes, can involve the entire autonomic nervous system, vasomotor, viscero-motor, and sensory fibers that innervate every organ. ${ }^{6}$ Many organs are dually innervated, receiving fibres from the parasympathetic and sympathetic divisions of the ANS. DAN typically occurs as a system wide disorder affecting all the parts of the ANS indeed, because the vagus nerve accounts for $75 \%$ of all parasympathetic activity ${ }^{7}$ and DAN manifests first in longer nerves, even early effects of DAN are widespread. The metabolic disorder of diabetes leads to diffuse and widespread damage of peripheral nerves and small vessels. One of the most overlooked complications of diabetes is Cardiac Autonomic Neuropathy. ${ }^{8}$ CAN results due to damage to the autonomic nerve fibers that innervate heart and blood vessels and it causes abnormalities in the heart rate and control vascular dynamics. ${ }^{9}$ Reduced heart rate variability is the indicator of CAN (cerebrovascular autonomic neuropathy). ${ }^{10}$ Therefore it is recommended that greater precautionary measures, similar to those for established cardiovascular disease, should be taken in patients with diabetes. These recommendations are based on the findings showing that cardiovascular disease occurs at a significantly higher rate in individuals with diabetes than in general population. ${ }^{10}$

The present study was carried out with the objectives 1 . To study the patter $\mathrm{n}$ of autonomic neuropathy in newly detected diabetic participants. 2. To assess the utility of HRV and specific bedside autonomic function test as a tool, for diagnosing cardiac autonomic neuropathy in diabetic patients.

\section{Materials and Methods}

This cross sectional study was conducted in 100 consecutive newly diagnosed type 2 diabetic cases age 35 to 50 years and fifty normal individuals attending medical OPD of Bapuji Hospital and Chigateri General Hospital attached to J.J.M. Medical College, Davangere from December 2006 to may 2007 involving.

Inclusion Criteria: Age 35 to 50 years, Patients who are biochemically proved type 2 diabetes. Both male and female having Non Insulin Dependent Diabetes were included in the study group, Patients who were not on any drugs that would interfere with the autonomic functions like anti hypertensives, vasodilators, phenothiazines, TCA's, and $\beta$ Blockers, Patients on anti diabetic treatment for less than 3 Months, Normal healthy control of both sexes between 3550 years age.

Exclusion Criteria: Presence of hypertension, Smokers, Presence of IHD. VHD, Heart failure, chronic alcoholic and 
alcohol dependent and patients with acute complications of diabetes mellitus like diabetic ketoacidosis, non-ketotic hyperosmolar coma and hypoglycemia.

Method of Collection of Data: A pre tested structured proforma were used to collect the relevant information regarding clinical findings, investigations and test results. These patients and normal individuals were subjected to 5 cardiovascular tests and heart rate variability after detail history regarding autonomic symptoms, peripheral neuritis and careful physical examinations.

The patients is placed supine on an examination table and allowed to rest for 5 minutes, they will be asked to breath regularly at 6 breaths per minute using Metronome and then they will be connected to ECG machine. The ECG recording is done and resting heart rate is calculated from this. Frequency Domain analysis is done by using NIVIQURE software.

Valsalva Maneuver: The patient was asked to perform the maneuver for a period of fifteen seconds. With the patient still connected to the ECG machine, he is then asked to release the pressure and an ECG is recorded for a further period of $30 \mathrm{sec}$. The patient is then allowed to rest for one minute and the procedure is repeated once again. He will be then allowed to rest for a further period of 1 minute. The ratio of the longest $\mathrm{R}-\mathrm{R}$ interval to the shorter $\mathrm{R}-\mathrm{R}$ interval during the maneuver is measured and result is expressed as Valsalva ratio which will be taken as the mean.

HR Response to Standing: the patient is allowed to rest for sometime, then the ECG recording is done for about 30 second in the supine position, patient was asked to stand up with ECG machine is running. When ECG baseline normal, the $15^{\text {th }}$ beat and the $30^{\text {th }}$ beat after standing up is marked. The characteristic heart rate response can be expressed by the 30:15 ratio.

Heart Rate Response to Deep Breathing: the patient was asked to deep breathing at the rate of 6 breaths per minute and the E/I ratio is calculated.

Power Spectral Analysis: Analysis of HRV will also be assessed by spectral analysis of series of successive R-R interval on 5 min ECG Recordings. The heart rate power spectrum is typically divided into two frequency bands. Low $(0.04-0.15 \mathrm{~Hz})$ and high frequency $(0.15$ to $0.4 \mathrm{~Hz})$.

Blood Pressure Response: Patient was again allowed to assume a supine position, and a recording of blood pressure was done. Patient was then instructed to stand up and blood pressure is recorded at 0 and 1 minute intervals.

Handgrip Test: The subject was told about the test and demonstrated the procedure to use handgrip dynamometer. After the instruction the subject is asked to grip using maximum force with their dominant hand for a few seconds. The value is noted down and the procedure is repeated thrice. The maximum value of the three readings is considered as their Maximal Voluntary Contraction (MVC). A mark is made on the dynamometer at $30 \%$ of MVC of the subject. He is then instructed that he will have to maintain the sustained grip on the dynamometer up to mark for 4 minutes. He is also told that if he is not able to maintain for full 4 minutes, then he must indicate the same to the investigator.

After the subject has started the contraction, the blood pressure (both) is measured on the contra-lateral arm at $1^{\text {st }}$, $2^{\text {nd }}, 4^{\text {th }}$ (or any time just before release of grip if it is less than $4 \mathrm{~min}$ ). One more reading is taken 2 minutes after the release of the grip.

QTc Interval: QTc interval is measured in baseline ECG recordings. Two consecutive QT intervals were measured in lead II of a standard ECG by 1 of 2 experienced observers by a computerized digitizer tablet. The QTc interval was measured form the beginning of the QRS complex to the visual return of the $\mathrm{T}$ wave to the isoelectric line and was heart rate-corrected with the Bazett formula, QTc $=Q T / \sqrt{ } \mathrm{RR}$ (resulting in a Pearson correlation coefficient between heart rate and QTc interval of 0.11 compared with a Pearson correlation coefficient between heart rate and the uncorrected QT interval of 0.73). A mean QTc interval was calculated from all QTc intervals measured. When the T wave is interrupted by a $U$ wave, the end of the $T$ wave is defined as the nadir between the $\mathrm{T}$ and the $\mathrm{U}$ wave. When the nadir is not defined, the lead is discarded from analysis.

\section{Results}

Resting HR: On comparison between controls and diabetic cases, the resting heart rate was higher in diabetics than normal. $(\mathrm{p}<0.05)$

BP Response to Standing: There was a decrease in SBP among controls and cases $(p<0.05)$. But there was no change in diastolic blood pressure in supine position between cases and controls.

Valsalva Ratio: It was decreased in diabetics as compared to controls.

E/I ratio: No difference was observed in E/I ratio between control and diabetics.

Hand Grip Test: In controls there was increase in systolic $\mathrm{BP}$ during test as compared to rest. There was increase in DBP during test. In cases systolic blood pressure was increase in during test as compared to rest. Similarly diastolic blood pressure was increase in during test when compared to rest.

Comparing blood pressure with the controls and cases, there was significant increase in the blood pressure during rest and the test (hand grip test).

Ratio of heart rate on standing decreased in cases as compared to controls. Table 1 
Table 1: Comparison of cardiovascular tests

\begin{tabular}{|c|c|c|c|c|c|c|c|c|c|c|c|c|c|}
\hline \multirow[b]{3}{*}{ 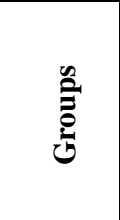 } & & \multirow{3}{*}{ 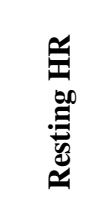 } & \multicolumn{4}{|c|}{ Postural } & \multirow{3}{*}{ 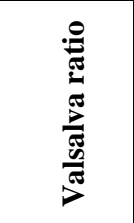 } & \multirow{3}{*}{ 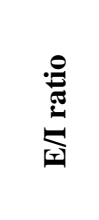 } & \multicolumn{4}{|c|}{ Handgrip test } & \multirow[b]{3}{*}{$\begin{array}{c}\text { HR } \\
(30: 15 \\
\text { ratio) }\end{array}$} \\
\hline & & & \multicolumn{2}{|c|}{ SBP } & \multicolumn{2}{|c|}{ DBP } & & & \multicolumn{2}{|c|}{ SBP } & \multicolumn{2}{|c|}{ DBP } & \\
\hline & & & 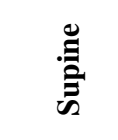 & : & $\stackrel{\mathscr{Z}}{\mathscr{Z}}$ & 象 & & & $\underset{\stackrel{\vec{n}}{2}}{\simeq}$ & $\stackrel{\overrightarrow{3}}{\stackrel{\theta}{*}}$ & $\stackrel{\overrightarrow{0}}{\mathscr{2}}$ & $\vec{E}$ & \\
\hline $\begin{array}{l}\text { Controls } \\
(50)\end{array}$ & $\begin{array}{l}\text { Mean } \\
\pm \text { SD }\end{array}$ & $\begin{array}{c}76.5 \pm \\
4.4 \\
\end{array}$ & $\begin{array}{c}123.9 \pm \\
7.2 \\
\end{array}$ & $\begin{array}{c}114.4 \pm \\
7.7 \\
\end{array}$ & $\begin{array}{c}75.9 \pm \\
4.8 \\
\end{array}$ & $\begin{array}{c}80.5 \pm \\
5.6 \\
\end{array}$ & $\begin{array}{c}1.27 \pm \\
0.02 \\
\end{array}$ & $\begin{array}{c}1.24 \pm \\
0.01 \\
\end{array}$ & $\begin{array}{c}113.6 \pm \\
7.1 \\
\end{array}$ & $\begin{array}{c}134.8 \pm \\
6.4 \\
\end{array}$ & $\begin{array}{c}75.4 \pm \\
4.6 \\
\end{array}$ & $\begin{array}{c}94.2 \pm \\
4.7 \\
\end{array}$ & $\begin{array}{c}1.04 \pm \\
0.06\end{array}$ \\
\hline \multirow{2}{*}{$\begin{array}{l}\text { Cases } \\
(100)\end{array}$} & $\begin{array}{l}\text { Mean } \\
\pm \text { SD }\end{array}$ & $\begin{array}{c}88.1 \pm \\
4.3\end{array}$ & $\begin{array}{c}120.6 \pm \\
9.5\end{array}$ & $\begin{array}{c}108.0 \pm \\
11.1\end{array}$ & $\begin{array}{l}75.1 \pm \\
4.5\end{array}$ & $\begin{array}{c}70.3 \pm \\
5.1\end{array}$ & $\begin{array}{c}1.24 \pm \\
0.03\end{array}$ & $\begin{array}{c}1.22 \pm \\
0.02\end{array}$ & $\begin{array}{c}111.9 \pm \\
3.9\end{array}$ & $\begin{array}{c}126.6 \pm \\
5.8\end{array}$ & $\begin{array}{c}74.6 \pm \\
4.5\end{array}$ & $\begin{array}{c}84.6 \pm \\
4.5\end{array}$ & $\begin{array}{c}1.06 \pm \\
0.04\end{array}$ \\
\hline & Range & $78-100$ & $100-132$ & $90-124$ & $70-96$ & $60-84$ & $1.20-1.33$ & $\begin{array}{l}1.21- \\
1.26\end{array}$ & $100-122$ & $110-138$ & $70-88$ & $70-98$ & $\begin{array}{l}1.00- \\
1.16\end{array}$ \\
\hline $\begin{array}{l}\text { Cases vs } \\
\text { Controls }\end{array}$ & $\mathrm{t}$-value & 51.7 & 2.15 & 3.65 & 0.93 & 11.2 & 8.96 & 0.08 & 1.83 & 7.93 & 7.93 & 10.3 & 2.13 \\
\hline
\end{tabular}

$\mathrm{P}<0.01$ significant $\mathrm{P}$ value $>0.05=$ Not significant

Resting HR: When the resting HR was analysed between all the three groups, there was a significant difference but in the normal range.

Response to supine- standing: The mean value of systolic blood pressure ( $\mathrm{mm}$ of $\mathrm{Hg}$ ) in supine was $123.9 \pm 7.2,127.5$ \pm 5.6 and $110.7 \pm 5.9$ among three Groups.

The mean value of SBP ( $\mathrm{mm}$ of $\mathrm{Hg}$ ) in standing was $114.4 \pm 7.7,116.3 \pm 4.5$ and $96.0 \pm 4.9$. There was slight fall in blood pressure.

The mean values of diastolic blood pressure $(\mathrm{mm}$ of $\mathrm{Hg}$ ) in supine position were $75.9 \pm 4.8,73.7 \pm 2.5$ and $77.2 \pm 5.7$ three Groups respectively. The mean values of DBP in standing position were $80.5 \pm 5.6,69.2 \pm 5.2$ and $72.0 \pm 4.5$ among Group I, II and III respectively. $\mathrm{P}<0.05$
Valsalva ratio: the difference observed between the groups were statistically significant but normal range.

E.I. Ratio: The range was 1.22 to $1.26,1.23$ to 1.26 and 1.21 to 1.24 among Group I, II, III.

Heart rate (beat/minute) response: The mean values were $1.06 \pm 0.0,1.05 \pm 0.02$ and $1.04 \pm 0.02$ respectively. $\mathrm{P}<0.05$ Handgrip: The mean values of systolic blood pressure $(\mathrm{mm}$ of $\mathrm{Hg}$ ) were $113.6 \pm 7.1,111 \pm 2.3$ and $112.1 \pm 5.5$ among Group I, Group II and Group III respectively. The systolic blood pressure during test in Group I, II and III ranged from 116 to 146,110 to $138,114-136$ respectively. There were significant increase in the values.

At rest the mean values of DBP $(\mathrm{mm}$ of $\mathrm{Hg}$ ) were $75.4 \pm$ 4.6, $72.6 \pm 2.4$ and $77.5 \pm 5.3$ among Groups. Whereas during test the mean values of the diastolic blood pressure were $94.2 \pm 4.7,81.6 \pm 3.4$ and $89.0 \pm 5.3$. This was statistical significant increase.

Table 2: Cardiovascular test between three groups

\begin{tabular}{|c|c|c|c|c|c|c|c|c|c|c|c|c|c|}
\hline \multirow{3}{*}{ 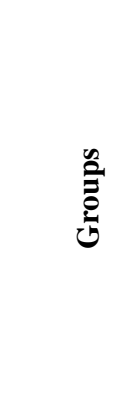 } & & \multirow{3}{*}{ 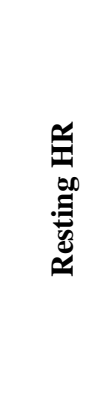 } & \multicolumn{4}{|c|}{ 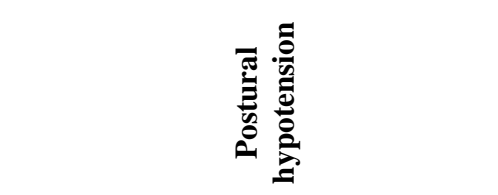 } & \multirow{3}{*}{ 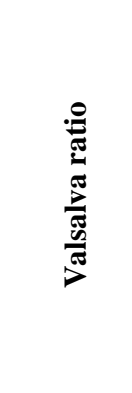 } & \multirow{3}{*}{ 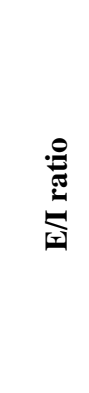 } & \multicolumn{4}{|c|}{ 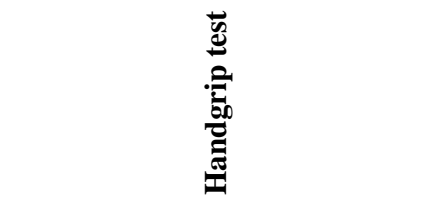 } & \multirow{3}{*}{ 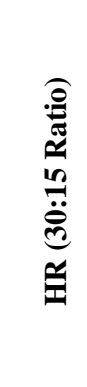 } \\
\hline & & & \multicolumn{2}{|c|}{ SBP } & \multicolumn{2}{|c|}{ DBP } & & & \multicolumn{2}{|c|}{ SBP } & \multicolumn{2}{|c|}{ DBP } & \\
\hline & & & $\stackrel{\mathscr{B}}{\stackrel{\Xi}{\Xi}}$ & $\underset{\tilde{D}}{\stackrel{0}{E}}$ & $\stackrel{\mathscr{E}}{\stackrel{\Xi}{\Xi}}$ & 泀 & & & $\begin{array}{l}\overrightarrow{y_{0}} \\
\simeq\end{array}$ & $\stackrel{\overrightarrow{0}}{E}$ & $\begin{array}{l}\vec{y} \\
\simeq \\
\simeq 4\end{array}$ & $\vec{E}$ & \\
\hline \multirow{2}{*}{$\begin{array}{l}\text { Group I } \\
(50)\end{array}$} & $\begin{array}{l}\text { Mean } \\
\pm \text { SD }\end{array}$ & $\begin{array}{c}76.5 \pm \\
4.4\end{array}$ & $\begin{array}{c}123.9 \pm \\
7.2\end{array}$ & $\begin{array}{c}114.4 \pm \\
7.7\end{array}$ & $\begin{array}{c}75.9 \pm \\
4.8\end{array}$ & $\begin{array}{c}80.5 \pm \\
5.6\end{array}$ & $\begin{array}{c}1.27 \pm \\
0.02\end{array}$ & $\begin{array}{c}1.24 \pm \\
0.01\end{array}$ & $\begin{array}{l}113.6 \\
\pm 7.1\end{array}$ & $\begin{array}{l}134.8 \\
\pm 6.4\end{array}$ & $\begin{array}{c}75.4 \pm \\
4.6\end{array}$ & $\begin{array}{c}94.2 \pm \\
4.7\end{array}$ & $\begin{array}{c}1.06 \pm \\
0.04\end{array}$ \\
\hline & Range & $68-86$ & $\begin{array}{l}110- \\
134\end{array}$ & $98-128$ & $70-86$ & $72-92$ & $1.24-1.30$ & $\begin{array}{l}1.22- \\
1.26\end{array}$ & $\begin{array}{l}100- \\
124\end{array}$ & $\begin{array}{c}116- \\
146\end{array}$ & $70-84$ & $\begin{array}{l}86- \\
104\end{array}$ & $\begin{array}{c}1.04- \\
1.14\end{array}$ \\
\hline $\begin{array}{l}\text { Group II } \\
\text { (59) }\end{array}$ & $\begin{array}{l}\text { Mean } \\
\pm \text { SD }\end{array}$ & $\begin{array}{c}86.8 \pm \\
2.1\end{array}$ & $\begin{array}{c}127.5 \pm \\
3.6\end{array}$ & $\begin{array}{c}116.3 \pm \\
4.5\end{array}$ & $\begin{array}{c}73.7 \pm \\
2.5\end{array}$ & $\begin{array}{c}69.2 \pm \\
5.2\end{array}$ & $\begin{array}{c}1.25 \pm \\
0.02\end{array}$ & $\begin{array}{c}1.25 \pm \\
0.01\end{array}$ & $\begin{array}{l}111.8 \\
\pm 2.3\end{array}$ & $\begin{array}{r}127.6 \\
\pm 5.6\end{array}$ & $\begin{array}{c}72.6 \pm \\
2.4\end{array}$ & $\begin{array}{c}81.6 \pm \\
3.4\end{array}$ & $\begin{array}{c}1.05 \pm \\
0.02\end{array}$ \\
\hline \multirow{2}{*}{$\begin{array}{l}\text { Group III } \\
\text { (41) }\end{array}$} & $\begin{array}{l}\text { Mean } \\
\pm \text { SD }\end{array}$ & $\begin{array}{c}90.0 \pm \\
5.7\end{array}$ & $\begin{array}{c}110.7 \pm \\
5.9\end{array}$ & $\begin{array}{c}96.0 \pm \\
4.9\end{array}$ & $\begin{array}{c}77.2 \pm \\
5.7\end{array}$ & $\begin{array}{l}72.0 \pm \\
4.5\end{array}$ & $\begin{array}{c}1.22 \pm \\
0.01\end{array}$ & $\begin{array}{c}1.22 \pm \\
0.01\end{array}$ & $\begin{array}{l}112.1 \\
\pm 5.5 \\
\end{array}$ & $\begin{array}{r}125.2 \\
\pm 5.8 \\
\end{array}$ & $\begin{array}{c}77.5 \pm \\
5.3\end{array}$ & $\begin{array}{c}89.0 \pm \\
5.3\end{array}$ & $\begin{array}{c}1.04 \pm \\
0.02\end{array}$ \\
\hline & Range & $78-100$ & $100-$ & 90-108 & $70-96$ & $60-84$ & $1.20-1.24$ & $1.21-$ & $100-$ & 114- & $70-78$ & $80-98$ & $1.04-$ \\
\hline
\end{tabular}




\begin{tabular}{|c|c|c|c|c|c|c|c|c|c|c|c|c|c|}
\hline & & & 120 & & & & & 1.24 & 122 & 136 & & & 1.07 \\
\hline \multicolumn{2}{|l|}{$\begin{array}{l}\text { ANOVA } \\
\text { p-value }\end{array}$} & \multicolumn{7}{|c|}{$<0.01$} & $>0.01$ & \multicolumn{4}{|l|}{$<0.01$} \\
\hline \multirow{3}{*}{$\begin{array}{l}\text { Difference } \\
\text { between } \\
\text { groups (p- } \\
\text { values) }\end{array}$} & $1-2$ & $<0.01$ & $<0.05$ & NS & $<0.05$ & $<0.01$ & $<0.01$ & $<0.05$ & NS & $<0.05$ & $\begin{array}{l}<.01 \\
\end{array}$ & $<0.01$ & $<0.05$ \\
\hline & $1-3$ & \multicolumn{3}{|c|}{$<0.01$} & NS & $<0.05$ & \multicolumn{2}{|c|}{$<0.01$} & NS & \multicolumn{4}{|c|}{$<0.01$} \\
\hline & $2-3$ & $<0.05$ & \multicolumn{2}{|c|}{$<0.01$} & \multicolumn{2}{|l|}{$<0.05$} & $<0.01$ & $<0.05$ & NS & \multicolumn{3}{|c|}{$<0.01$} & $<0.05$ \\
\hline
\end{tabular}

Low frequency: The low frequency mean value in controls was $0.11 \pm 0.08$, Group II was $0.09 \pm 0.09$ and in Group III was $0.08 \pm 0.04$. $(\mathrm{p}<0.05)$.

High frequency (HF): The mean value of high frequency in Group I was $0.38 \pm 0.08$. The mean value of high frequency in Group II was $0.31 \pm 0.06$. The mean value of high frequency in Group III was $0.23 \pm 0.08$. $(\mathrm{p}<0.01)$.

Low frequency to high frequency ratio (LF/HF): Mean value of this ratio in controls was $0.40 \pm 0.25$, in Group II was $0.39 \pm 0.30$ and in group III was $0.34 \pm 0.19$. No significant decrease observed among controls and Group II and among controls and Group III. Table 3

No significant decrease of high frequency values among controls and Group II, but there was a decrease among controls, Group II and Group III (P < 0.05). In regards with ratio, no significant decrease among all the groups was found.

Table 3: Comparison of HRV between Group I, II and III

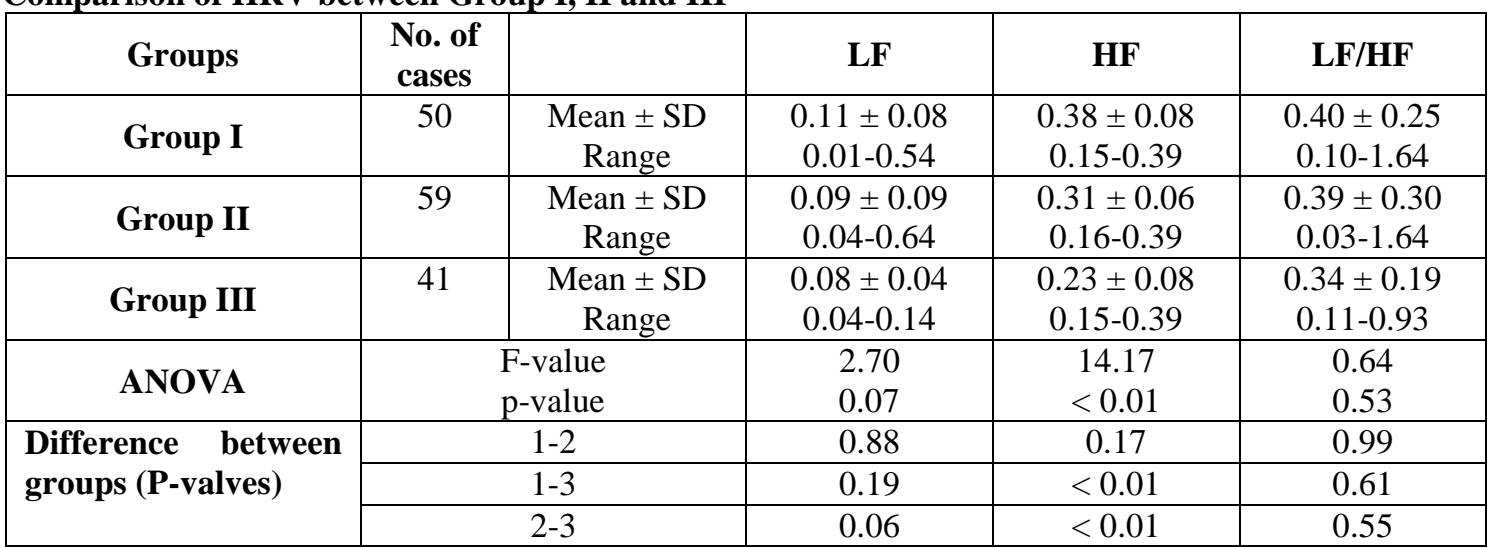

QTe Interval: QTc interval were increased in Group II and II as compared to Group I. Similarly QTc interval increased in Group III. The differences observed was statistically significant.

Table 4: Comparison of QTc values between different groups

\begin{tabular}{|c|c|c|c|}
\hline Groups & No. & $\begin{array}{c}\text { Mean } \\
\text { QTc } \pm \text { SD }\end{array}$ & Range \\
\hline I. Controls & 50 & $406.9 \pm 19.9$ & $384-470$ \\
\hline II. Diabetics CAN ' 0 ' & 59 & $412.8 \pm 21.6$ & $384-482$ \\
\hline III. Diabetics CAN > '0' & 41 & $432.6 \pm 18.9$ & $398-463$ \\
\hline Total & 150 & \multicolumn{2}{|c|}{ ANOVA, $\mathrm{F}=19.3 \mathrm{P}<0.01$} \\
\hline
\end{tabular}

\section{Discussion}

In our study the resting heart rate was increased in group II and III to Group I. These findings are in concurrence with other studies. Many studies, ${ }^{11-14}$ have suggested that increase in resting HR in diabetics was mainly due to parasympathetic damage in early stage of cardiac autonomic involvement. Normally parasympathetic inhibit heart rate and damage results in increased heart rate. There is fall S\&D blood pressure on standing. There was a fall in blood pressure in Group II and III. Low PA ${ }^{15}$ and Langer ${ }^{16}$ have suggested that this may be due to damage to the efferent sympathetic vasomotor fibers particularly in the splanchnic vasculature.
The valsalva ratio decreased in Group II \& III. American Diabetes Association ${ }^{17}$ suggested that Valsalva maneuver involving both pathways to the heart, sympathetic pathways to the vascular tree, baroreceptors in the chest and lungs. The baroreflex system is impaired in diabetics. As a result the response is altered.

On studying the response to BP to handgrip test, diastolic BP was diminishes in Group II and III. Ewing DJ ${ }^{18}$ suggested that when a normal person performs sustained isometric exercise, the heart rate and cardiac output increased to a modest degree while the BP response is more marked. But in diabetics the blood pressure decreased due to 
decrease in the vascular resistance and impaired sympathetic activity.

The E: I ratio was decreased in Group II and III. Rathmann ${ }^{19}$ suggested that the heart rate increases during inspiration and decreases on expiration. Sinus arrhythmia is primarily mediated by the vagal innervation. The neuronal out put from the respiratory centre influences the gain of the afferent and efferent outputs at the nucleus tractus solitarius. Pulmonary stretch receptors as well as cardiac mechanoreceptors contribute to regulating the heart rate variation. But in diabetics due to the impairment of parasympathetic system the ratio decreases.

On comparing the heart rate response to standing the value decreased in Group II and Group III. Ewing DJ ${ }^{21}$ observed that lying to standing test is mediated by sympathetic and parasympathetic reflex pathways. In diabetics with autonomic neuropathy there is abnormal response due to damage to the reflex pathways, mediating the response.

The low frequency value decreased in II and III. Marek $^{21}$ observed that reduction of the absolute power of high frequency was seen in diabetic patients without evidence of autonomic neuropathy. It is mainly due to impaired parasympathetic system.

Low frequency was not significant different between the groups.

QTc interval was more than $440 \mathrm{msec}$ in diabetic cases. $\mathrm{Kahn}^{22}$ and Bellavere ${ }^{23}$ observed that $\mathrm{QT}_{\mathrm{C}}$ is mainly due to sympathetic imbalance and it is agreed that parasympathetic have little influence on $\mathrm{QT}_{\mathrm{C}}$ interval.

\section{Conclusion}

It was concluded that hand grip test and QTc intervals have shown some promise as useful tests for screening diabetic patients for cardiac autonomic neuropathy, However, a larger prospective study is required in evaluating usefulness of these tests.

\section{Conflict of Interest: None.}

\section{References}

1. Dyck PJ, Katz KM, Karnes JL, Litchy WJ, Klein R, Pach JM, Wilson DM, O' Brich PC, Melton LJ, Service FJ. The prevalence by staged severity of various types of diabetic neuropathy, retinopathy and nephropathy in a population-based Cohort: Rochester Diabet Neuropathy Study Neurol 1993;43:817-824.

2. Young MJ. Boulton AJM, Melcod AF, Wiliams DRR, Sonksen $\mathrm{PH}$. A multicentre study of the prevalence of diabetic peripheral neuropathy in the UK hospital. Clinic population. Diabetologia 1993;36:150-156.

3. Kumar S, Ashe HC, Parnell LN, Fernando DJ. Tsigose, Yound RJ. Ward JD, Boulton AJM: The prevalence of foot ulceration and its correlates in type 2 diabetes: a population- based study. Diabet Med 1994;11:450:484.

4. Cabezas, Cerrato J: The prevalence of diabetic neuropathy in Spain: a study in primary and hospital clinic groups. Diabetologia 1998;41:1263-1269.

5. Freeman R. The peripheral nervous system and diabetes. In Weir G, Kahn R, King GL, edts. Joslin's Diabetes Mellitus. Philadelphia: Lippincott; 2002.
6. American diabetes association and American Academy of Neurology: Report and recommendations of the san Antonio conference on diabetic neuropathy (Consensus statement). Diabetes 1988;37:1000-1004.

7. Ziegler D. Cardiovascular autonomic neurophaty: clinical manifestations and measurement. Diabetes Rev 1999;7:300315.

8. Horrobin DF. Essential fatty acids in the management of impaired nerve function in diabetes. Diabetes 1997;46(2):S90S93.

9. Brownlee M. Glycation products and the pathogenesis of diabetic complications. Diabetes Care 1992;15:1835-1843.

10. Obrosova IG. How does glucose generate oxidative stress in peripheral nerve? Intern Review Neurobiol 2002;50:3-35.

11. Clarke BF, Ewing DJ, Campbell IW. Diabetic autonomic neuropathy. Diabetologia 1979;17:195-212.

12. Ewing DJ, Clarke BF. Diabetic autonomic neuropathy : a clinical viewpoint. In: Dyck PJ, Thomas PK, Asbury AK, Weingrad AI, Porte D, edts. Diabetic Neuropathy. Philadelphia: WB Saunders; 1987:p.66-88.

13. Tornlinson DR. Polyols and myointosital in diabetic neuropathy of mice and men. Mayo Clin Proc 1989;64:1030.

14. Veglio M, Simeri R, Chinaglia A, Scaglione L, Cavallo-Perin P. QT interval prolongation and mortality in type I diabetic patients : a 5-year cohort prospective study : Neuropathy study group of the Italian Society of the study of diabetes, Piemonte Affiliate. Diabetes Care 2000;23:1381-1383.

15. Low PA, Warsh JC, Huang CY, McLeod JG. The sympathetic nervous system is diabetic neuropathy; a clinical and pathological study. Brain 1975;98:341-356.

16. Langer A, Freemann MR, Josse RG, Steiner G, Armstrong PW. Detection of silent myocardial ischemia in diabetes mellitus. Am J Cardiol 1991;67:1073-1078.

17. American diabetes association : Consensus statement : Autonomic nervous system testing. Diabetes Care 1992;15(Suppl 3):1095-1103.

18. Ewing DJ, Campbell IW, Clarke BF. The natural history of diabetic autonomic neuropathy. Q J Med 1980;49(193):95-108

19. Rathmann W, Ziegler D, Jahnke M. Mortality in diabetic patient with CAN. Diabetic Med 1993;10:820-824.

20. Ewing DJ, Campbell IW, Murray A, Neilson JMM, Clarke BF. Immediate heart rate response to standing: simple test for autonomic neuropathy in diabetes. Br Med J 1978;1:145-7.

21. Malik M. Heart rate variability, standard of measurement, physiological interpretation, and clinical use. Am Heart Ass Circ 1996;93(5):1043-1065.

22. Katri JK, Sisson JC, Vinik AI. QT interval prolongation and sudden cardiac death in diabetic autonomic neuropathy. $J$ Clin Endocrinol Metabol 1987;64(4):751-4.

23. Bellavere F, Ferri M, Quarini L. Prolongation of QT period in diabetic autonomic neuropathy. A possible role in sudden cardiac death. Br Heart J 1988;59:379-383.

How to cite this article: Prakash SB, Md. Shariff EA.
Evaluation of cardiovascular autonomic function in
diabetics and normal individual by using standard
autonomic function tests and heart rate variability.
Indian J Clin Anat Physiol 2019;6(1):27-31.

